\title{
FREEDOM OF EXPRESSION AND DECRIMINALIZATION OF THE DEFAMATION IN THE REPUBLIC OF MACEDONIA
}

\author{
Andon Majhosev ${ }^{1}$ Goran Mirkovski ${ }^{2}$ \\ ${ }^{1}$ University "Goce Delchev"- Stip, Faculty of Law, Macedonia \\ ${ }^{2}$ MA student at the Department of Law - "Goce Delchev" University, Shtip, Macedonia \\ andon.majhosev@ugd.edu.mk; goran.mirkovski@ replek.com.mk
}

\section{Professional Paper \\ doi:10.5937/jouproman5-14634}

\begin{abstract}
The freedom of expression is one of the most important human civil and political rights which is guaranteed with many international and regional legal instruments established by UN, European Council, EU and etc. That is basic precondition for the development of one country. The freedom of expression includes not only the freedom to express one's opinion or ideas but it also includes freedom to search information or ideas, receive informations or ideas and to pass the informations or ideas.
\end{abstract}

In many countries in the world, as well in Macedonia, the freedom of expression is not absolute but limited and the border is the respect of the freedom and the rights of other people, more specifically their reputation and honour.

Reporters often deliberately or unintentionally, while doing their job, violate the right of freedom of speech by insulting or defaming others, most common public function holder (politicians).

The politicians with their political power significantly influenced on the judicial organs so that they reach a verdict in their favor. Therefore the reporters were exposed to great pressure and very often they were punished by jail sentences. Setting the judicial system this way it became limiting factor in the normal development of the reporters job.

Until 2012 the insult and the defamation in Republic of Macedonian were considered criminal act and they were subjected to jail punishment.

Since the law of civil liability for insult and defamation in 2012, the insult and the defamation don't belong to corpus delicti that are in the sphere of the criminal right.

Since then to this day the insult and the defamation are treated as violation.

Key words: Law, insult, defamation, violation, punishment

\section{- Freedom of expression}

Viewed historically, the freedom of speech was developed as a permanent fight of the man with the authority that used to forbid or limit the freedom of expression. The political freedom and rights express the political subjectivity of the citizen and give him opportunity to take part in the political life of the community (the state). Freedom of expression is democratic right and essential expression of democracy. Thus this right is one of the central rights from whose existence or non-existence in great amount depends on the achievement of the other political rights and freedom which are guaranteed with the European Convention on Human Rights. The freedom of speech rises out of the basic human natural right- right of freedom. That means that without freedom there are no free persons neither freedom of the society. 
As a result of that basic right there are other special rights of freedom such as freedom of spirit and freedom in communicating with other people. Within the freedom of the spirit are the freedom of the thought and the conscience and the freedom of expression of opinions and ideas - freedom of providing information.

One analysis made with 142 world constitutions revealed that 124 of them have guarantee of freedom of speech and only 66 constitutions forbid torture or cruel, inhuman or humiliating behavior.

The freedom of speech allows that every person and also every professional reporter has right to express his own opinion freely and nobody can prevent that (not even the state, or the authority or the opposing party). If somehow, with certain procedures by person, group or institutions "the expression of the opinion, announcement and revealing of facts, data, events are questionable or limited, there is no democratic public or democracy. With Article 10 of the ECHR the protection of the freedom of speech refer to the informations and the point of view expressed by a small group of people or one person even if that kind of opinion is unacceptable for the majority. In this direction, John Stuart Mill rejecting the tyranny of the majority has interesting opinion "If all mankind minus one, were of one opinion, and only one person were of the contrary opinion, mankind would be no more justified in silencing that one person, than he, if he had the power, would be justified in silencing mankind".

Case Thorgeir Thorgeirson: June 1992 in the case Thorgeir Thoreirson against Iceland for the conviction of the applicant (the reporter) after the publishing of two articles in one paper for alleged police brutality. The first article had form as a letter addressed to the Minister of Justice who was called to "form a committee to investigate the rumors, gradually becoming public opinion, that there is more and more brutality within the Reykjavik police force and being hushed up in an unnatural manner." The reporter points out only one reporter who was the victim of the police brutality. Describing the police he wrote" because you are the Minister of Justice and thus in command of those wild beasts in uniform that creep around, silently or not, in the jungle of our town's night life...the young man's roommates told me that his injuries had been inflicted by bouncers of a restaurant and some policeman. At first I could not believe this, so I enquired among the hospital stuff and -Yes, they were right; we had there a victim of the Reykjavik night squad." The reporter (applicant) in his second article emphasizes that "the police behavior was so typical of what is gradually becoming the public image of our police force defending itself: bullying, forgery, unlawful actions, superstitions, rashness and ineptitude."

\section{A legitimate restriction on freedom of expression}

According to Art. 10 paragraph 2 of the European Convention on Human Rights, freedom of expression may be restricted by reason of:

1) Interest in state security;

2) Territorial integrity or public security;

3) Protection of order, prevention of unrest and crimes; 
4) Protection of the reputation and rights of others

5) Protection from disclosure of confidential information

6) Maintaining the authority and impartiality of the judiciary

It seems that the list of "legitimate aims" is quite broad from the aspect of journalistic freedom. In order to apply some measure of restricting freedom of expression, there must be a "strong social need" for it. If there is such a "strong social need", the state has a wide range of measures for the protection of legitimate aims at its disposal, and what measures will be applied, falls into its disposition. However, in a proceeding before the Court in Strasbourg, there will be an obligation to prove that in order to achieve that legitimate aim, there was no milder measure that could be effectively used in the appropriate case. Thus, the Court in Strasbourg retains the authority to decide whether the national authorities have presented relevant and sufficient evidences for justification of measures applied.

\section{Definition of insult and defamation}

The insult and the defamation in the Republic of Macedonia have been decriminalized since 2012 when the Law on Civil Liability for Insult and Defamation was passed. This Law was brought for making clear that for disruption of honor and reputation of any Macedonian citizen you can't pronounce punishment but that the offended person can proceeded a case at the Civil court for reimbursement of eventual immaterial harm. The main need for the existence of legal institute of insult is to protect the honor and reputation of any subject (persons and institutions). Regulations of this Law determines the bounders of freedom of criticism, and from where the critic crosses the line to something that should be sanctioned, for protecting the honor and reputations of subjects.

According to the Law, insult is defined as :"For insult is responsible the person who with intention to humiliate, by statement, acting, publishing or by any other way express humiliating opinion, that insult his honor and reputation". 1

In article 7 from the Law on Civil liability for insult and defamation, are defined the bases of exclusion the responsibility. According to this article, for insult will not be responsible if:

- If you transmit statement given in working process in Assembly of the Republic of Macedonia, in working process in Counsels in municipalities, in administrative or judicial proceedings or in front of Ombudsman, only if prosecutor proves that it is given maliciously,

- if you transmit opinion from official document of all levels of Power,

- if you transmit announcement and documents of international organizations and conferences,

- if you transmit announcement and document for public information given by Competent state authorities, institutions and other legal entities,

- if you transmit announcement or other official document from investigation of committed criminal offences,

\footnotetext{
${ }^{1}$ Article 6 of the Law on Civil Liability for Insult and Defamation
} 
- if you transmit statement by witch you transmit opinions from public gathering, court case or any other public manifestation of activities official institutions, associations ore legal entities, or

- if you report a statement that is already pronounced by other.

Also, it is not considered responsible for offence the person who makes humiliating opinion for any Holder of public office if he proves that:

- it is based on facts,

- if he had basic reason to believe in truthfulness of the facts,

- if statement has justified critic or it encourage a public debate,

- if statement is given in accordance with professional standards and ethics of journalist profession.

In accordance with the provisions of the Law, it is not considered responsible for insult the one who makes negative opinion for other person with sincere intention or confidence in the benevolence of his opinion, if the critic is expressed in scientific, literary and artistic work, during official serving of duty, journalism or politic if he offence:

- freedom of expression, public interest,

- if there is no insult, significant injury or if it is not said exclusively to humiliate a person.

Definition of defamation: unlike the insult, according the Law on Civil liability for insult and defamation, defamation is considered for harder work that violates the honor and reputation of citizen. In the Law, definition for defamation is: "For defamation is responsible the subject that for other subject with established identity, with intention to harm his honor and reputation, in front of third subject express or sais untrue facts that harms his honor and reputation, but he knows or he should knows that the facts are not true.",2

This definition contains international standards of defamation, and according to this, for defamation is responsible only if there is case of publishing untrue facts, that means that true facts are not consider as defamation even when they violate the honor and reputation of a person.

\section{Exclusion of the liability for defamation}

The exclusion of the liability for defamation is regulated by the Law on Civil Liability. In accordance with the provisions of the Law, several bases are determined according to which journalists may be exempted from liability. No one will be held liable for defamation for claiming harmful facts about the honor and the reputation of another if the statement is given: ${ }^{3}$

- in a scientific, literary or artistic work,

- in a serious criticism in the performance of an official duty,

- in the performance of a journalistic profession,

- in the performance of a political or other social activity,

- in defense of the freedom of expression of thoughts or other rights,

- in the protection of the public interest or other reasonable interests.

\footnotetext{
2 Article 8, paragraph 1 of the Law on Civil Liability for Insult and Defamation

${ }^{3}$ Article 10 of the Law on Civil Liability for Insult and Defamation
} 


\section{Decriminalization of the defamation in the Republic of Macedonia}

Defamation and insult belong to the corpus of torts that are found in the sphere of criminal law. Prior to the adoption of the Law on Civil Liability for Insult and Defamation, these torts were part of the group of penal (criminal) acts, which were regulated by a separate chapter. Sometimes, in performing their profession, journalists do not provide objective information in their texts intentionally or unintentionally, or they violate the dignity and the honor of the citizens through defamation. Any legal system, including that of the Republic of Macedonia, provides indemnification for individuals whose reputation has been damaged by the speech of others. Freedom of expression implies freedom of public speech, but also freedom of artistic expression.

In the past few years, the decriminalization of defamation in the Republic of Macedonia was a central issue and a topic of discussion between the Government of the Republic of Macedonia and the Association of Journalists of Macedonia (ZNM). An intensive dialogue was carried out between the Government of the Republic of Macedonia and ZNM for decriminalization of defamation. In order for ZNM to solve this problem, with the support of the EU, an initiative for amendment of the Law on Criminal Procedure was launched, according to which the criminal act of defamation should be treated as a misdemeanor instead of a crime. To solve this problem, an open dialogue was carried out between the Government and the Association of the
Journalists of Macedonia (ZNM). ZNM's proposal was to decriminalize defamation, or to transform it into a misdemeanor penalty instead of a criminal punishment. Thereupon, steps were taken towards the implementation of reforms in the legislation of the Republic of Macedonia which deal with the decriminalization of defamation. After several years of debate, in November 2012, the Assembly of the Republic of Macedonia adopted the two legal proposals of the Government and ZNM, the amendments to the Criminal Code and the Law on Civil Liability for Defamation and Insult. Most of the acts against honor and reputation were erased with the first law, by which no prison sentence was determined for such acts, and the second law established liability for such acts in the civil law.

Over 700 court cases for defamation and insult are amnestied, half of which filed against journalists.

Categorical (cascade) liability for defamation and insult is introduced among the journalist, the editor and the media, and a maximum limit for compensation of non-pecuniary damage is determined to 27 thousand euros (2 thousand for the journalist, 10 thousand for the editor, and 15 thousand for the medium).

\section{Why decriminalization of insult and defamation?}

The idea for decriminalization of insult and defamation was triggered by the community of journalists, which lobbied through the Association of Journalists for erasing the acts connected to violation of honor and reputation according to the Criminal Code and adoption of a special bill that will regulate the liability for insult and defamation. 
The Association of journalist had its arguments for these demands.

One of the arguments was that there is a danger that pronouncement of jail sentences for insult and defamation could lead to negative implications on the freedom of expression because journalists would start to avoid writing about delicate questions, for which there is a possibility that they will be sued and get drastic jail sentences and fines. The European Court of Human rights in Strasbourg has issued its own opinion on this matter, and according to it, jail sentences for acts against honor and reputation are not proportional and can possibly scare journalists and media.

The second reason for decriminalization of insult and defamation were the numerous private criminal lawsuits against journalists that the Association of journalists had claimed they were used as a tool of pressure and intimidation.

Third, most of the lawsuits against journalists were submitted by carriers of public functions that possess huge political powers. The journalists complained that politicians use these lawsuits to silent journalists by discouraging them from intentions to write about their work.

Four, judicial proceedings for insult and defamation against journalists used to last for several years and that was also a way of continuous pressure and uncertainty. This resulted in selfcensorship of the journalists, aiming at avoiding any new lawsuits.

Fifth, by acting according to the Criminal Law, judges pronounced extremely high fines as a compensation for defamation against journalists. For example, in the Case Crvenkovski against
Mladenov, the journalist Nikola Mladenov was fined with 25000 Euros. For the same text the owner of the weekly newspaper Fokus, Nikola Mladenov had lost the case, which the former prime minister Hari Kostov had filed against him, and Mladenov was fined another 15000 Euros, making the overall fine of 40 thousand Euros for the text concerning the alleged secret bank accounts of the president in that period Branko Crvenkovski.

Sixth, often the Criminal Courts demanded the journalists to prove that their claims in the texts are true, on the contrary they pronounced them guilty of insult and defamation and pronounced un proportional sentences without taking into consideration the important role that media have in an democratic society as a watch $\mathrm{dog}$, as creators of public opinion and encouragement of debate on topics of public interest. In the Article 5of the Law, a broad definition of topics concerning public interest, about almost all the spheres of public living, is provided. Topics of public interests are considered to be all forms, institutions and activities of public governing and public institutions, local governing, public services such are health care, culture, art, education, science, sports, media, law system and applying Law and economic system and economic relations and environment ${ }^{4}$.

Due to all these reasons, the Association of Journalists demanded annulations of prison sentences for insult and defamation, considering it as a disproportional sentence for protecting one's respect and honor, as well as sharing the liability between the publisher, editor and journalist.

\footnotetext{
${ }^{4}$ Article 5, paragraph 2 of the Law on Civil Liability for Insult and Defamation.
} 
This request was based on the fact that in most of the lawsuits, journalists were the only ones found liable, without taking into consideration the liability for approving and publishing the texts by publishers and editors. The journalists were the only ones that were fined.

\section{Conclusion}

The freedom of expression is a fundamental civil and political right and a pillar of the public democracy. The freedom of expression is not an absolute one, and its limits are considered to be the freedom and rights of others. The freedom of expression as a universal and democratic value is highly endangered on a global level. If a journalist is attacked, this is an attack on the truth in order for such semi truth or lie to win, if a camera is broken, it is an attack on the freedom of media and expression. The greatest danger comes from the economic or political power centers, which often succeed in controlling the media. In some countries with autocratic rule there is a practice of killing or imprisoning media workers. A country is considered more democratic if more of these rights are respected.

The freedom of expression is a battle that cannot be completely won. As long as there is a state and a Government, limitations of freedom of press and freedom of expression are going to exist. The greatest danger for freedom of expression and freedom of media comes from the Government. The censorship and self-censorship are forms of limitations of the freedom of expression. As achieving of higher public aims and higher public interest is at stake, the journalist should make a balance between information and the security of the state.

Up until 2012, the insult and defamation in the Republic of Macedonia had a status of criminal acts, and jail sentences were pronounced. By accepting the Law on Civil Liability for Insult and Defamation in 2012, they have been extracted from the corpus of torts that are in the Criminal Law sphere of interest. Since then, the insult and defamation are treated as offense. The object of preserving in the area of insult and defamation are the honor and respect of the physical or legal subject, as well as the freedom of expression. The Law on Civil Liability for Insult and Defamation does not give space for the public function carriers to sue in their official standings as President of the state, Prime minister, minister etc. They are able to sue as physical subjects do.

Also, the Law on Civil Liability for Insult and Defamation provides the possibility that before filing a Lawsuit, the person that believes his/her honor and respect have been offended, can demand for an apology or public withdrawal of the statement (Article 13), or deny, answer or correction (Article 14 ) in a period of two days. When a lawsuit has been filed against a journalist or media, the procedure is a matter of high priority.

\section{References}

[1] Alvin Dej, L., (2000). Etika u medijima, Medija centar, Beograd, Klio.

[2] Bal, F., (1997). Moć medija, Clio, Beograd.

[3] Breton, F., (2000). Izmanipulisana reč. Clio, Beograd.

[4] The Publics Right to Know, Principles on Freedom of Information Legislation: 
Article 19, London;

[5] Korni, D., (1999). Etika informisanja, Clio, Beograd.

[6] Zakon za gradjanska odgovornost za navreda i kleveta (Sl. Vesnik na RM br.143/12)

[7] Zaket, D. (2007). Novinarska etika moralna odgovornost u medijima, Služben glasnik.

[8] Evropska konvencija za čovekovi prava (1950), Sovet na Evropa.

[9] Galbrajt, Dž.K. (1995). Anatomija na moćta. Kultura, Skopje.

[10]https//:okno.mk/node/5098

[11]Majhošev, A., (2015). Novinarska etika (avtorizirani predavanja), UGD, Štip.

[12]Makovej, M., (2001). Sloboda na izražuvanje, Vodič za implementacija na člen 10 od Konvencijata za čovekovi prava, Sovet na Evropa. 